\title{
The Role of Online Ads on Dynamics of Consumer Behavior
}

\author{
Paramitha Kinanti ${ }^{1}$, Inge Hutagalung ${ }^{2}$ \\ \{kinanti1104@gmail.com¹, inge_hutagalung@mercubuana.ac.id $\left.{ }^{2}\right\}$ \\ Universitas Mercu Buana, Jakarta, Indonesia ${ }^{12}$
}

\begin{abstract}
This study aims to determine the role of online advertising on the dynamics of consumer behavior. The researchers' argument is based on the number of online promo advertisements with a payment system through mobile payment developed to attract consumer buying intentions. The research paradigm is constructivism. The research method used in the study is Interpretative Phenomenological Analyzes (IPA), with data collection techniques through depth interviews. The results showed that advertising must be adjusted to the type of consumer behavior. For rational type consumers, advertising messages must be made through rational appeals. That is, advertising messages are facts as well as information about products that will be able to convince consumers about the usefulness of the product, and are delivered in an informative manner. Furthermore, in digital advertising messages will be processed referring to the AISAS (Awareness, Interest, Search, Action, Share) model. In the AISAS model, advertising messages will be search with reference groups to be discussed, and determine the stages of action. Experience in using the product will be shared with peer groups through online media. Meanwhile, consumer behavior as recipients of persuasion messages will experience dynamics depending on the learning process of the behavior experienced. Satisfaction with consumers will make consumers to buy or re-use products. In the end, three hypotheses were concluded as a result of research, namely (1) the more ads have relevance to needs the more attractive consumers will be to see/read advertisements. (2) The more rational the way consumers think, the dynamics of consumer behavior will be in the operant position (the position based on profit and loss). (3) The greater the reference group's support for an advertisement, the more it will strengthen consumer action.
\end{abstract}

Keywords: online advertising, type of consumer, need of consumer, advertising messages, reference groups

\section{Introduction}

Since the advent of the internet in the early 1990s, advertisers have found various ways to promote their products and services through online advertising. Now many online promo advertisements with payment systems through mobile payment have been developed to attract consumers' buying intentions. Online advertising is a form of communication that is based on the assumption of individual beliefs and psychological perceptions. When individuals are exposed to online advertising on social media cognitive message processing will occur. The results of Rucker and Petty's research conducted with qualitative methods confirm that the Elaboration Likelihood Model (ELM) can be used to persuade consumers 
regarding changes in attitude to take purchasing decision actions [1]. Communication messages that use the elaboration likelihood model approach are considered effective because they can raise consumer awareness and help consumers recognize the product. When consumers have a high involvement in the product, the consumer will process the message through the main channel, in contrast to consumers who have a low involvement in the product, the message will be processed through the periphery by learning the signals that can strengthen attitudes until the consumer finally believes and makes a purchase decision.

Furthermore, Kitchen [2], Yang [3] and Prashar [4] shows that the development of the ELM model in the field of marketing communication has caused changes in the media environment and the way consumers process advertising exposure. Yang's research results indicate that the use of digital media increases the initial trust of consumers to make purchases (initial trust in mobile-shopping services) [3]. While the results of Prashar's research confirm that consumers are interested in buying after being overwhelmed by online advertising messages that have benefits as needed [4].

On the other hand, research conducted by Alkatiri [5], Linda [6], Putra [7], and Ivoni [8] stated that the attractiveness of online advertising is at discounted prices which have a significant effect on consumer buying interest. Furthermore, the results of Ivoni's research suggest that brands do not influence consumers to buy products [8]. Consumers do not consider the brand as important, for the most important consumers are price promos. Meanwhile, Hadikusuma's research [9] shows that social influence has a significant effect on online product purchases. Confirming the previous study, Zhou [10], Afwa [11] and Hutagalung [12] research explained that risk and trust significantly influence online shopping satisfaction. This means that consumers have considered the risk factors of online shopping transactions and have a high level of trust to make online shopping transactions.

Based on the phenomena and previous studies, researchers argue that previous studies only looked at the attractiveness of online advertising on consumer buying interest. Buying interest is consumer behavior, which is a decision-making process of consumers in choosing, buying, using and utilizing products or services in order to satisfy the needs and desires of consumers. Basically, consumer behavior is generally divided into two, namely consumer behavior that is rational and irrational [13]. Realizing that consumer behavior is a dynamic, researchers see a gap research and are interested in conducting research with a research question is how is the role of online advertising related to the dynamics of consumer behavior to buy a product?

\subsection{Literature Review}

\subsubsection{Elaboration Likelihood Model (ELM) Theory}

The Elaboration Likelihood Model (ELM) was introduced by Richard Petty and John Cacioppo. Early ideas about ELM were written by Petty and Cacioppo in the early 1980s, and elaborated in detail in a book entitled Communication and Persuasion: Central and Peripheral Routes to Attitude Change (1986). The Elaboration Likelihood Model (ELM) is a form of persuasion theory that sees individuals as rational beings when evaluating persuasion messages. According to ELM theory, a person evaluates information in various ways, sometimes evaluating messages carefully, using critical thinking, but sometimes simpler, sometimes arguing spirit, but sometimes not. That possibility depends on the way someone processes the message.

Persuasion messages that emphasize strong arguments and facts (central route) are more likely to have an effect on changing one's attitude than persuasion messages that do not rely on argumentation (peripheral route), such as highlighting stars or actors. One of the strengths 
of ELM theory compared to other persuasion theories is that it describes the process of influencing and changing attitudes systematically into a model. This theory is also applicable, applicable and has been widely used by many companies to measure the effectiveness of persuasion messages.

Petty and Cacioppo see two important aspects that determine how a persuasion message is processed by someone. First, a person's motivation for receiving persuasion messages (such as advertisements) [14]. The higher the relevance of the message to someone the higher the motivation of someone to receive the message and the desire to know the contents of the message. Second, one's ability to process persuasion messages. Someone can be interested and have motivation to process a message, but if that person does not have the ability to process messages then the persuasion message will not be processed either. The two factors above (motivation and ability to process messages), determine whether a message will be processed or elaborated by someone or not. A message that is processed and elaborated, by Petty and Cacioppo, is called using the central route. Instead, a message that is not elaborated will be processed using a peripheral route.

\subsubsection{Consumer Behavior}

Consumer behavior is the process that individuals or groups go through to choose, buy, use, and evaluate products or services in meeting their needs and wants [15]. Marketers recognize that consumer decision making is an ongoing process before consumers pay cash and receive goods or services. There are three aspects of consumer processes: cognition or thought, influence or feeling, and behavior. Cognition and feelings cannot be observed directly, it is necessary to rely on people to articulate their thoughts and feelings. On the other hand, behavior can be observed directly such as witnessing consumers while shopping, making purchases, using products, and sharing experiences with other consumers both online and offline.

Basically, consumer behavior is generally divided into two, namely consumer behavior that is rational and irrational [13]. The main characteristic of rational consumers is seeing advertisements that suit their needs. Meanwhile, the main characteristic of irrational consumers is that they are quickly attracted to advertisements and promotions in both print and electronic media.

\subsubsection{Behavioral Learning Theory}

According to behavioral learning theory there are two types of behavioral dynamics, namely classical conditioning and operant conditioning. Classical conditioning considers that behavior is a close association between the main stimulus (primary stimulus) with the second stimulus (secondary stimulus). For example, in an advertisement described the characteristics of successful people (primary stimulus) and also a brand of cigarette products such as Ardath (secondary stimulus). In classical conditioning it is hoped that the smoker Ardath brand associates himself like a successful person. Classical conditioning will be more effective if the main stimulus is something new and the primary stimulus is not associated with other product brands.

Then, the second type of behavior learning theory is operant conditioning, meaning when consumers know that their actions can result in a reward or punishment [15]. Operant conditioning or instrumental conditioning views behavior as a function of consumer action (buying behavior) and consumers' assessment of the degree of satisfaction obtained from actions. Satisfaction felt by consumers will cause reinforcement and will increase the possibility of repurchase. For example, when a consumer buys something on the product and 
gets a gift package then the consumer will make a repeat purchase. Consumers make repeat purchases because they feel satisfaction and become loyal.

\section{Research Method}

This study uses a constructivism paradigm using a qualitative approach with a case study method. The research method used in the study is Interpretative Phenomenological Analyzes (IPA) or Interpretative Phenomenological Analysis [16]. The key informant criteria in this study are millennial/generation $\mathrm{Y}$ who are at least 25 years old, and actively shop online more than five times and make payments through the mobile payment application. This study uses a semi-structured interview method as a method for collecting data. The technique used in measuring the validity of the data of this study is the triangulation technique. In this study the triangulation technique used was checking interview data with the concepts or supporting theories used in the study. Meanwhile, the argument of researchers choosing the OVO mobile payment application to be the focus of research is because OVO has an educational element related to the culture of saving. This element does not exist in other mobile payment applications

\section{Results and Discussion}

Informants in this study amounted to 3 people. In the presentation of the results of this study, the three informants used the initials in accordance with the agreement, namely, one (1) male sex person (HM) and two (2) female sex people (JA, SS).

Questions are divided into 4 parts, namely 1) knowledge of OVO advertising; 2) processing messages according to ELM Theory; 3) consumer behavior; 4) the dynamics of consumer behavior.

\subsection{Knowledge of OVO advertising}

The informants stated that they first got information about OVO from promo advertisements seen at the Mall related to parking payments. They understand OVO as a digital payment instrument that can be used not only for parking payments but also for payment for other shopping goods transactions. Furthermore, the informants expressed an interest in OVO because of the contents of the message from the advertisement, as well as an interest in images and large fonts. As for the long-term use of OVO, the informants stated that they had used OVO since the first time the OVO digital payment application was introduced to the public as an alternative to digital-based payment instruments. In the context of this study, the informants stated that OVO prepaid cards have many advantages compared to similar cards.

On many OVO cards there are promos, very easy card refilling, cash back in the form of points can be used for shopping and lots of collaboration with many merchants, which is not found on other prepaid cards. The informants also stated that OVO advertisements were easy to understand. The percentage of cash back is clear and informative so that it can be easily understood and understood. 


\subsection{Processing of messages according to ELM Theory}

The informants agreed that the OVO advertising message was very informative and easy to understand. The purple color of the ad is very interesting and distinguishes OVO ads from other ads. The ad letters are clearly legible and the ad content presentation is not excessive. On the other hand, the informants also emphasized the interest in OVO advertisements because the contents of the message were in accordance with the need to get the convenience of payment transactions when shopping.

\subsection{Consumer behavior}

In the context of this study, the informants agreed that they were not likely to be interested in seeing advertisements that had nothing to do with needs. Furthermore, the informants said that the advertisements are numerous and offer a variety of promos, but only the advertisements that have benefits and are related to personal needs. Furthermore, the informants stated that it was necessary to be selective in seeing OVO advertisements that were in accordance with purchasing power so that they were not trapped in a consumptive lifestyle. In viewing advertisements, avoid seeing advertisements just because you want to try a product, or just because it pretends.

\subsection{Dynamics of Consumer Behavior}

In the context of this study, the informants agreed that the environment and friendship had a greater role than the promotion of advertising as a driver to see OVO ads. Furthermore, the informants emphasized that the selection of OVO advertisements was not due to lifestyle but rather because of a need to find convenience in making payment transactions. This study wants to know the process of consumer interest in online advertising messages and the dynamics of consumer behavior related to online advertising exposure. The research discussion will begin by looking at the position of communication in marketing. The researcher's argument starts the initial discussion of the position of communication in marketing because advertising is one of the marketing communication mix.

After examining the position of advertisements in communication magnification, researchers based on the results of the study will see how the advertising message must be packaged in order to play a role in persuading consumers in the stages of action to buy. After that the discussion will look at online advertising planning models, and see what conditions play a role in the dynamics of consumer behavior related to persuasion of advertising messages.

\subsection{Advertising as a Marketing Communication Mix}

One form of communication in human life is marketing. Marketing with communication has a close relationship. The basis of marketing is communication, and marketing itself is a communication concept. Marketing can be very powerful if combined with effective and efficient communication. One approach used is to integrate the marketing approach with communication, known as integrated marketing communication. One form of IMC activities is advertising. Advertising has the function to persuade people or groups of people to buy a product.

On the other hand, advertising is seen as creating false desires that are not really desired by consumers. Advertising often suggests making the acquisition of desires from consumers towards the goal of achieving happiness and success in the personal lives of consumers. Advertising often creates false awareness. 


\subsection{The Role of Advertising in Persuading Consumers}

In general, two approaches in advertising, namely rational appeals and emotional appeals. Rational appeals emphasize more on the functions and uses of an advertised product, including the benefits to consumers when using the product. That is, what is advertised is facts and information about the product that will be able to convince consumers about the usefulness of the product. Meanwhile, emotional appeals are approaches in advertising that relate to situations and conditions of the social and psychological needs of consumers related to the decision to buy a product.

From the results of the study it appears that the informants are interested in OVO advertisements because OVO advertising messages represent the needs of consumers regarding actions to make payments more easily than conventional payment systems. On the other hand, the informants have the ability to process advertising messages with critical thinking. This is evident in the answers of the informants who said they understood the meaning of OVO advertisements, chose to see OVO advertisements on the basis of the contents of advertising messages, and confirmed that OVO has advantages over similar digital prepaid cards.

From the statements of these informants, it can be categorized that the informants are classified as rational consumers. Namely, consumers who process advertising messages based on facts and information about the product and product usability.

\subsection{Consumer Dynamics in Online Advertising}

Associated with the results of the study, it appears that the communication model carried out by the informants in viewing OVO advertisements refers to the AISA model, namely Awareness, Interest, Share, and Action. Stages of awareness in this study is the understanding that the use of digital prepaid cards can also be used as savings. Furthermore, the informants are increasingly interested because in OVO advertising messages there are many promos and ease of transactions when shopping. After understanding the contents of the OVO advertising message, the informants stated that the message was shared and discussed in the community of friends. Finally, it was decided to buy an OVO card after entering into an agreement in a group that OVO has the advantage of similar online payment cards.

From the results of this study it appears that advertising through digital has different message processing stages with the AIDDA planning model (Awareness, Interest, Desire, Decision, and Action). In the AISA model, advertising messages are processed by sharing messages with reference groups through digitization. While in the AIDDA model, advertising messages are processed individually. According to researchers, this happens because the current era of digitalization is changing the communication approach. Traditional mass media which basically offer a "one-for-many" communication model (eg: newspapers, television, radio) become "many-for-one" (use of email, websites) and "manyfor-many" (use of mailing lists, cell phone groups or electronic discussions).

\subsection{Consumer Dynamics and the Environment}

The communication model in online advertising is carried out through the AISAS stage. Namely, share the message to the reference group to be followed up on the next action. At this stage it appears that the environment or reference group plays a role in the action stage. From the results of the study it can be seen from the informants' statements stating that the environment has a role in purchasing OVO prepaid cards. 
Furthermore, the informants take action also because of operant conditioning, meaning that when people know that their actions can result in rewards or punishment, individuals will perform certain behaviors. Operant conditioning or instrumental conditioning views behavior as a function of consumer action (buying behavior) and consumers' assessment of the degree of satisfaction obtained from actions. From the results of the study, it appears that the informants chose OVO because they found it easy to shop, either because of the large OVO promos or because the digital prepaid card system was felt to be more flexible than conventional payments. The informants also expressed satisfaction with the use of OVO prepaid cards as presented in the recommendations.

Finally, related to the role of online advertising in the dynamics of consumer behavior it is necessary to understand that the advertising messages obtained will be shared with a reference group to determine the next stage, namely action.

\section{Conclusions}

In general, from the research results it can be concluded that Ads must be adapted to the type of consumer behavior. That is, for a rational type of convention the advertising message must be made through a rational approach (rational appeals). That is, advertising messages are facts as well as information about products that will be able to convince consumers about the usefulness of the product, and are delivered in an informative manner. Consumer behavior as recipients of persuasion messages will experience dynamics depending on the behavior learning process experienced. Satisfaction with consumers will make consumers to buy or re-use products. For example, when a consumer buys something on a product and then gets a gift/promo package, the consumer will make a repeat purchase.

In digital advertising, the message will be processed according to the AISAS model: Awareness, Interest, Search, Action, and Share. In the AISAS model, attractive advertising messages will be searched and discussed with reference groups, to determine the stages of action. After that, consumers will share experiences using the product to reference groups by providing testimonials on social media or telling friends or family about the product. Finally, this research produces a hypothesis, namely a) the more ads have relevance to the needs, the more attractive consumers will be to see/read advertisements; b) the more rational the way consumers think, the dynamics of consumer behavior will be in the operant position (a position based on profit and loss); c) the greater the reference group's support for an advertisement, the more it will strengthen consumer action.

\section{References}

[1] R. E. Rucker, D. D., and Petty, "Increasing the Effectiveness of Communications to Consumers: Recommendations Based on Elaboration Likelihood and Attitude Certainty Perspectives," Am. Mark. Assoc., vol. 25, no. 1, pp. 39-52, 2006.

[2] H. J. Kitchen, P., Kerr, G., E. Schultz, D., McColl, R., dan Pals, "The Elaboration Likelihood Model: Review, Critique and Research Agenda,” Eur. J. Mark., vol. 48(11/12), pp. 20332050, 2014.

[3] S. Yang, "Role of Transfer-Based and Performance-Based Cues on Initial Trust in Mobile Shopping Services: a Cross-Environment Perspective.," Inf. Syst. E-bus. Manag., vol. 14, no. 1, pp. 47-70, 2015. 
[4] C. Prashar, S., Sai Vijay, T., and Parsad, "Effects of Online Shopping Values and Website Cues on Purchase Behaviour: A Study Using S-O-R Framework.,"Vikalpa, vol. 42, no. 1, pp. $1-18,2017$.

[5] F. Alkatiri, S., Tumbel, A. L., and Roring, "Effect of Attractiveness Advertisements and Discounts on Consumer Purchase Interest in Matahari Department Store Manado Town Square,” J. Ris. Ekon. Manajemen, Bisnis dan Akunt., vol. 5, no. 2, pp. 178-192, 2017.

[6] L. Fitria, A. Winata, and D. Permana, "The Effect of Electronic Coupon Value to Perceived Usefulness and Perceived Ease-of-Use and its Implication to Behavioral Intention to Use Server-Based Electronic Money,” vol. 5, no. 1, pp. 147-158, 2020.

[7] L. D. R. Putra, N. I., Pangestuti, E., and Devita, "The Effect of Discounts and Gift Giving on Impulsive Purchases in Retail Fashion (Online Survey on Matahari Department Store Consumers in Malang Town Square).," J. Adm. Bisnis, vol. 61, no. 4, pp. 1-9, 2018.

[8] A. Ivoni, D., Santika, I. W., and Suryani, "The Influence of Price Perception, Brand Orientation, and Shopping Orientation on Intention to Buy Fashion Online," E-Jurnal Manaj. Unud, vol. 4, no. 4, pp. 898-911, 2015.

[9] F. Hadikusuma, S., and Jaolis, "The Influence of Social Influence, Perceived Usefulness, and Perceived Security Against Continue Use Intention Mobile Payment OVO Application Through Attitude Towards Using Mobile Payment As Intervening Variables Among Students of the Faculty of Business," AGORA, vol. 7, no. 2, pp. 1-6, 2019.

[10] T. Zhou, "The Effect of Initial Trust on User Adoption of Mobile Payment," Inf. Dev., pp. 27(4), 290-300, 2011.

[11] L. Afwa, A., Samsir, and Sulistyowati, "Analysis of the Effect of Technology Perception, Risk Perception on Trust and Its Impact on Student Online Shopping Satisfaction in Pekanbaru," J. Ekon., vol. 22, no. 3, pp. 1-15, 2014.

[12] I. Hutagalung, "Selective Exposure and Consumer Behavior (Interpretative Phenomenological Analysis in Consumer Behavior of Adolescent Generation Z in Selecting The Ad Information of Smartphone),” Int. J. Organ. Innov., vol. 9, no. 2, pp. 85-104, 2016.

[13] M. A. Firmansyah, Consumer Behaviour. Yogyakarta: Deepublish., 2019.

[14] R. and J. T. C. and J. P. Petty, To Thinks or Not to Think: Exploring Two Routes to Persuasion, 2nd ed. Thousand Oaks: Sage Publication., 2005.

[15] E. W. Solomon, M. R., Marshall, G. W., and Stuart, Marketing: Real People, Real Choice, 8th ed. England: Pearson Education Limited, 2015.

[16] O. Smith, Jonathan A., and Mike, Qualitative Psychology: Practice Instruction for Research Methods. Yogyakarta: Pustaka Pelajar, 2009. 